\title{
Pengujian Monitoring On-Line Rumah Kaca Cerdas Berbasis Android
}

\author{
Diana Rahmawati ${ }^{1}$, Miftachul Ulum ${ }^{1}$, dan Heri Setiawan ${ }^{3}$ \\ ${ }^{1}$ Prodi Teknik Elektro, Jurusan Teknik Elektro, Fakultas Teknik Universitas Trunojoyo Madura \\ JL. Raya Telang PO BOX 2 Kamal Bangkalan Madura \\ ${ }^{3}$ Prodi Elektronika Sistem Senjata, Jurusan Teknik Elektro, Politeknik Angkatan Darat Malang \\ Kesatrian Artileri Pendem Junrejo Batu \\ e-mail:diana.rahmawati@trunojoyo.ac.id,miftachul.ulum@trunojoyo.ac.id, hsetiawan@ymail.com
}

\begin{abstract}
Abstrak - Rumah kaca yang didesain adalah rumah kaca cerdas berbasis android. Sistem kendali pada rumah kaca ini menggunakan kontrol logika fuzzy untuk mengatur parameter-parameter input suhu tanaman, kelembapan udara, kelembapan tanah, dan cahaya. Output berupa pompa, kipas, dan lampu. Sistem bekerja secara otomatis sesuai set point kebutuhan tanaman yang diinputkan. Jika parameter inputan berubah, sensor akan melaporkan ke sistem, dan sistem akan melakukan aksi sesuai yang diprogramkan, agar semua berjalan sesuai seperti set point. Sistem ini dihubungkan dengan android, sehingga petani dapat memonitor kondisi tanaman dalam rumah kaca secara on-line. Dalam prosedur perancangan, diperlukan pengujian sistem rangkaian yang dirakit. Akan dilakukan pengujian sistem per blok, dan kemudian dilakukan pengujian sistem terintegrasi. Hasil yang diperoleh, sistem bekerja dengan baik sesuai dengan aturan fuzzy.
\end{abstract}

Kata kunci : monitoring, on-line, rumah kaca, android, fuzzy

Abstract - The greenhouse that is designed is an intelligent greenhouse based on Android. The control system in this greenhouse uses fuzzy logic controls to set input parameters for plant temperature, air humidity, soil moisture, and light. Output in the form of pumps, fans and lights. The system works automatically according to the set point of the plants inputted. If the input parameters change, the sensor will report to the system, and the system will act according to the programmed, so that everything goes according to the set point. This system is connected to Android, so farmers can monitor the condition of plants in the greenhouse on-line. In the design procedure, an assembled circuit system is needed. System testing will be carried out per block, and then integrated system testing is carried out. The results obtained, the system works well according to fuzzy rules.

Keywords : monitoring, online, greenhouse, android, fuzzy

\section{PENDAHULUAN}

Teknologi rumah kaca merupakan teknologi yang menjadi solusi masalah pertanian saat ini. Masyarakat urban membutuhkan hasil tanaman yang dapat dinikmati sepanjang musim. Permasalahan yang dihadapi adalah musim yang tidak menentu. Hal ini tentu saja sangat mempengaruhi tumbuh kembang tanaman. Dengan teknologi cerdas rumah kaca, masalah musim dapat teratasi. Tanaman dalam rumah kaca dapat diatur sesuai kondisi yang dibutuhkan tanaman tersebut. Dengan tercapainya kondisi tumbuh kembang yang sempurna, diharapkan akan memperoleh hasil sesuai dengan yang diinginkan. Tanaman dapat tumbuh dan berkembang serta dipanen sepanjang musim, karena iklim diciptakan di dalam rumah kaca.

Untuk lebih memberdayakan sektor pertanian perlu upaya untuk lebih mengefisienkan dan menggunakan caracara yang lebih modern. Salah satu cara tersebut adalah menggunakan sistem pertanian dengan menggunakan rumah kaca, yang selanjutnya disebut pertanian rumah kaca.
Pertanian rumah kaca mempunyai banyak keuntungan, diantaranya : mudah dalam mengendalikan hama dan penyakit, dapat mengendalikan suhu dan kelembaban serta dapat lebih meningkatkan mutu produk pertanian yang dihasilkan. Meskipun demikian cara ini memerlukan biaya yang relatif lebih tinggi dan intensitas energi (energi yang digunakan per unit produksi) juga lebih besar dibandingkan dengan cara konvensional. Karena energi merupakan salah satu faktor penting, maka pengendalian sistem energi merupakan salah satu faktor untuk dapat menekan biaya produksi.

Sistem pertanian rumah kaca mempunyai beberapa keuntungan diantaranya mudah dalam mengendalikan hama dan penyakit, meningkatkan produksi dan mutu produk yang dihasilkan. Disamping itu, sistem ini banyak memerlukan tambahan energi sehingga biaya produksinya juga akan meningkat pula. Untuk mengurangi penggunaan energi dapat digunakan arduino untuk kendali sistem energinya. Parameter yang dikendalikan meliputi suhu, kelembaban, irigasi, dan penerangan. Dengan otomatisasi, akan mengurangi penggunaan energi sia-sia. Selain itu, 
pada sistem ini ditambahkan fitur monitoring dan setting inputan kondisi melalui android menggunakan Wireless Sensor Network.

Pada artikel ini, akan disajikan uji coba rangkaian per blok, kemudian uji fungsional rangkaian keseluruhan.

\section{TINJAUAN PUSTAKA}

Pahruzi Muhammad, dkk. membuat rancang bangun alat penyiraman otomatis menggunakan sensor SHT75 berbasis mikrokontroller ATMEGA8535. Kelebihan dari penelitian ini adalah berhasil membuat alat penyiraman otomatis menggunakan sensor SHT75 berbasis mikrokontroller ATMEGA 8535 dengan supply energi yang digunakan terdiri dari kombinasi sel surya (50WP), BCR $(12 \mathrm{~V})$ batterai $(50 \mathrm{AH})$ yang tegangan outputnya sebesar 9VDC yang mampu untuk mensuplai mikrokontrolloer sehingga bisa melakukan penyiraman otomatis. Kekuranganya adalah apabila masuk musim hujan alat ini tidak bekerja dengan maksimal dikarenakan alat ini menggunakan sel surya.[1]

Yusuf Muhammad, dkk. membuat implementasi robot line follower penyiraman tanaman otomatis menggunakan metode PID. Kelebihan dari penelitian ini adalah berhasil membuat robot line follower penyiraman tanaman otomatis dengan area penyiraman yang luas. Kekuranganya adalah biaya pembuatan alat mahal, kemampuan robot hanya $85 \%$ pada percobaan 15 kali tidak bisa maksimal 100\%.[2]

Widhi Happy Nugrahaning, Winarno Heru. meneliti tentang sistem penyiraman tanaman anggrek menggunakan sensor kelembaban dengan program borland delphi 7 berbasis modul arduino uno R3. Kelebihan dari penelitian ini adalah berhasil membuat sistem penyiraman tanaman anggrek menggunakan sensor kelembaban dengan program borland delphi 7 berbasis modul arduino uno R3. Kekurangan dari penelitian ini adalah proses penurunan suhu cukup sulit karena desain miniatur rumah kaca yang terbuat dari bahan acrylic, dimana bahan ini menyerap panas.[3]

Gupta Abhishek, dkk. meneliti tentang sistem penyiraman tanaman otomatis dengan deteksi kelembapan tanah. Penlitian ini dilakukan karenakan di India sumber air sangat kurang sehingga banyak tanaman mati tidak mendapatkan air. Kelebihan dari penelitian ini adalah berhasil membuat sistem penyiraman tanaman otomatis dengan mikrokontroler. Kekurangan dari penelitian ini adalah sensor hanya kelembapan sehingga kurang kompleks.[4]

Pada penelitian R. Diana $\mathrm{dkk}$, untuk mengurangi penggunaan energi dapat digunakan mikrokontroler untuk kendali sistem energinya. Parameter yang dikendalikan meliputi suhu, kelembaban, irigasi, penerangan, dan kadar CO2. Pada penelitian ini dilakukan perancangan sistem otomatisasi parameter rumah kaca yang dikendalikan. Dengan otomatisasi, akan mengurangi penggunaan energi sia-sia. Selain itu, pada sistem ini ditambahkan fitur monitoring dan setting inputan kondisi melalui sms(short message service).[5]

Penelitian tentang sistem mikroirigasi fuzzy otomatis menggunakan arduino telah dilakukan. Penelitian dengan judul "Perancangan Kebun Mini Hemat Air dengan Sistem Mikroirigasi Fuzzy Otomatis menggunakan Arduino" ini, dilakukan penyiraman otomatis terhadap tanaman, sesuai inputan dari sensor. Dengan menggunakan sentuhan teknologi seperti mikrokontroler, sensor, insinyur, dan penghobi bercocok tanam, dapat mengembangkan sistem yang dapat mengurangi biaya perawatan tanaman seminimum mungkin. Contoh sederhana penghematan perawatan adalah pada penyiraman. Dengan menggunakan irigasi tetes, salah satu tipe irigasi, dapat menghemat penggunaan air jika diaplikasikan. Air disuplai secara berkala, berdasar kondisi kelembaban tanah dan suhu, untuk menghemat sumber daya air. Penelitian ini memberikan desain penyiraman otomatis. Pada proyek ini digunakan kontroler arduino. Digunakan sebuah LCD $16 \mathrm{x}$ 2 yang dihubungkan dengan arduino, yang menunjukkan level kelembaban tanah dan temperaturnya. Perhitungan lama penyiraman dihitung secara scientific, untuk memperoleh perhitungan penggunaan air yang efisien. Perhitungan ini menggunakan fuzzy inference system untuk menghitung kebutuhan air, dan durasi penyiraman.

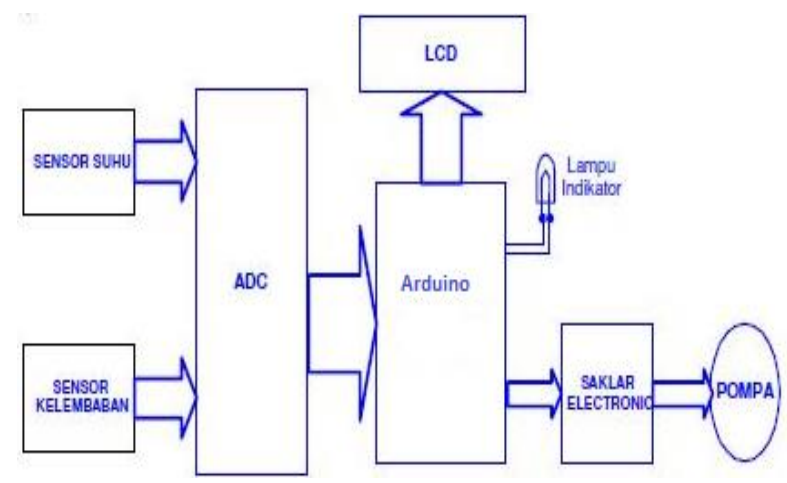

Gambar 1 Blok Diagram Sistem Penyiraman Otomatis

Pada dasarnya Sistem Pengairan Otomatis ini merupakan sistem yang dapat mengkontrol pompa air untuk digunakan mengairi lahan pertanaman secara otomatis. Adapun sistem otomatis atau kontrol pada pompa air menggunakan mikrokontroler Atmega 8 berdasarkan sensor kelembaban tanah dan sensor suhu. Tidak hanya mengkontrol pompa, tapi sistem juga dapat menampilkan berapa kelembaban tanah dan suhu tanah melalui Liquid Crystal Display. Sehingga diharapkan dengan adanya sistem ini maka pengairan akan lebih efektif dan efisien. Sistem pengairan otomatis ini menggunakan metode Sprinkle Irigation System, yaitu pengairan dengan pancaran dengan menggunakan pipa - pipa yang dilubangi (Kartasapoetra,1994).

Inisialisasi awal ketika perangkat dinyalakan akan membaca kelembaban tanah melalui Sensor Kelembaban tanah. Data yang diterima sensor akan diproses arduino. Apabila bit kelembaban kurang dari ambang atas maka pompa akan hidup. Pompa akan hidup seterusnya hingga mencapai ambang atas. Ketika mencapai ambang atas pompa otomatis mati. 


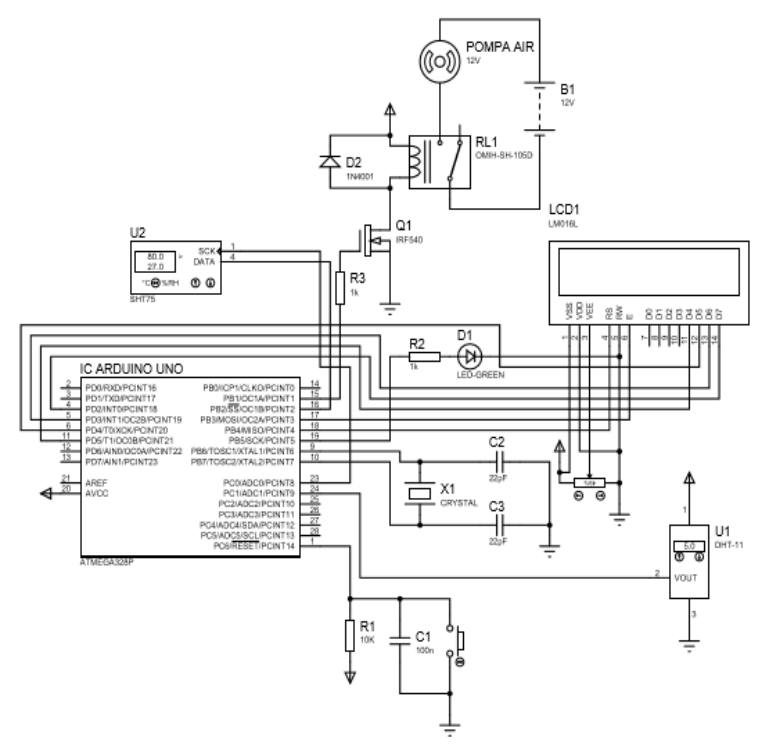

Gambar 2 Blok Diagram Rangkaian Arduino

Cara kerja sistem secara umum berdasarkan pada blok diagram sistem adalah sebagai berikut :

1. Seluruh kinerja dari sistem dikendalikan oleh arduino sesuai dengan perintah yang telah diatur oleh perangkat lunak.

2. Pada saat sistem diaktifkan, maka sistem melakukan inisialisasi terhadap seluruh aktuator, menampilkan nama pembuat sistem beserta nimnya. Setelah itu sistem akan membaca besaran-besaran fisis berupa suhu dan kelembaban melalui sensor-sensor. Data yang diperoleh akan ditampilkan di layar LCD.

3. Perintah penyiraman pompa disesuaikan dengan rule aturan fuzzy, yang disesuaikan dengan kebutuhan tanaman sawi. Jika suhu dan kelembaban kurang dan dibutuhkan penyiraman, maka sistem akan membaca sensor dan mengaktifkan pompa, dan durasi penyiraman disesuaikan dengan pengaturan dari sistem fuzzy.

4. Sistem akan kembali ke langkah 3 secara berulangulang.

Pada saat ujicoba, dengan menggunakan inputan suhu $290 \mathrm{C}$, dan kelembaban tanah 475, pompa air menyala dan menyalakan air dengan durasi 6,5 menit. Hasil dari prototipe mendekati hasil simulasi, dengan nilai eror $0,17 \%$.[6]

Hasil pengujian sistem fuzzy pada penelitian ini juga dipresentasikan pada seminar SNTT 2015, dengan judul" Desain Sistem Mikroirigasi Percik Otomatis berbasis Logika Fuzzy" (Rahmawati, Diana, 2015). Pada makalah ini diajukan sistem pengairan otomatis pada kebun mini dengan prinsip mikroirigasi. Selain untuk menghemat air, sistem pengairan otomatis ini dapat menghemat energi. Untuk itu diperlukan suatu sistem pengendalian khusus. Dalam hal ini akan diterapkan suatu metode berbasis fuzzy logic tipe mamdani yang mempunyai dua parameter utama, yaitu suhu dan kelembaban tanah. Diharapkan dengan metode ini dapat diatur lama penyiraman yang dibutuhkan oleh tanaman tersebut.

Pengkontrolan pompa air ini nantinya akan diimplementasikan untuk pengairan yang berdasarkan kelembaban tanah dan suhu tanah menggunakan metode
Fuzzy Inference System ke dalam hardware Open Source Arduino uno. Sistem ini diharapkan mampu mengairi tanah sesuai dengan karakteristik tumbuhan sawi daging(pokchoy).[7]

Penelitian tentang irigasi otomatis juga pernah diseminarkan dalam seminar internasional ICVEE 2015 dengan judul "Design and Simulation of Mini Garden Fuzzy Microirrigation System" (Rahmawati, Diana, 2015), dilakukan simulasi sistem penyiraman otomatis pada kebun mini dengan menggunakan MATLAB.[8]

\section{UJI COBA RANGKAIAN}

3.1 Rangkaian Sistem

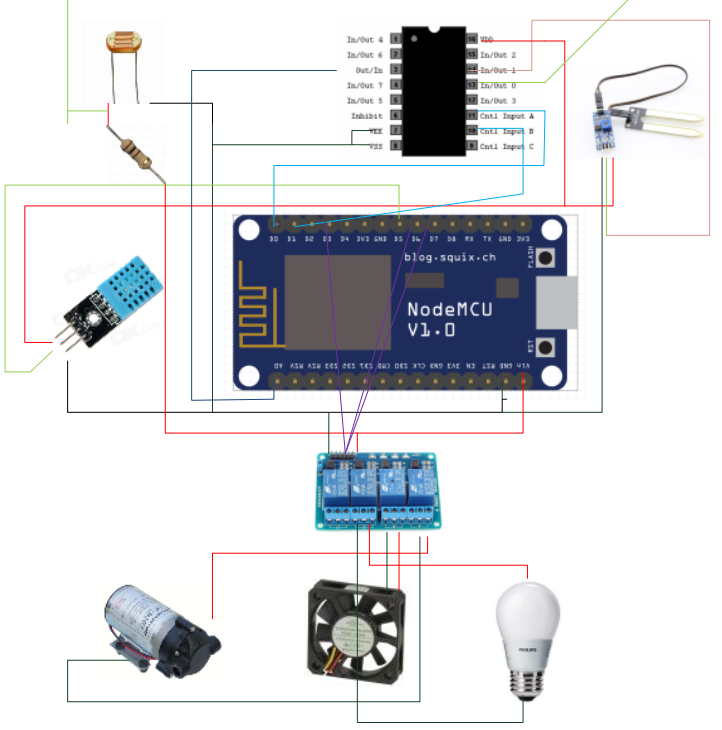

Gambar 3. Rangkaian sistem kontroler alat penyiraman

Rangkaian kontrol alat penyiraman otomatis dapat dilihat pada gambar 3 dapat dilihat dimana input adalah sensor dan output adalah aktuator. Input penyiraman ini berupa DHT-11, sensor soil moisture, dan sensor LDR. Node MCU adalah mikrokontroler yang memproses dari nilai sensor akan melakukan tindakan terhadap aktuator.

Aktuator alat penyiraman ini adalah pompa booster untuk menyemprot air, kipas untuk mendinginkan ruangan, dan lampu untuk menerangi jika gelap. Untuk jelasnya dapat dilihat pada gambar 3.

\subsection{Pengujian Rangkaian}

\subsubsection{Pengujian Node MCU (Mikrocontroller Unit)}

\section{A. Tujuan Pengujian}

Tujuan pengujian Node MCU ini adalah untuk memastikan mikrokontroler ini berfungsi dengan baik. Karena Node MCU sebagai otak dari alat ini. Untuk membaca sensor sehingga dapat menemukan nilai dari sensor tersebut dan dikirim ke suatu perangkat sehingga dapat dibaca oleh manusia.

\section{B. Peralatan Pengujian}

Peralatan yang digunakan untuk pengujian Node MCU ini adalah :

1. Mikrokontroler + modul ESP (Node MCU)

2. Kabel data USB 
3. Laptop

4. Software pemograman Arduino

\subsubsection{Pengujian Sensor DHT 11}

\section{A. Tujuan Pengujian}

Tujuan dari pengujian sensor DHT 11 bertujuan untuk mndapatkan nilai suhu dan kelembaban udara pada suatu ruangan. Nilai analog dari sensor akan diubah menjadi parameter suhu(C) dan kelembaban(\%) ruangan sesuai dengan kebutuhan.

\section{B. Peralatan Pengujian}

Peralatan yang dibutuhkan untuk pengujian sensor DHT 11 adalah :

1. Mikrokontroler Node MCU

2. Sensor DHT 11 dan modulnya

3. Kabel data usb

4. Kabel jumper

5. Software arduino

6. Libary DHT 11

\subsubsection{Pengujian Sensor Moisture}

\section{A. Tujuan Pengujian}

Tujuan dari pengujian sensor soil moisture bertujuan untuk mndapatkan nilai kelembaban tanah. Nilai analog dari sensor akan diubah menjadi parameter kelembaban dalam bentuk satuan persen(\%) sesuai dengan kebutuhan

\section{B. Peralatan Pengujian}

Peralatan yang dibutuhkan untuk pengujian sensor soil moisture adalah :

1. Mikrokontroler Node MCU

2. Sensor soil moisture dan modulnya

3. Kabel data usb

4. IC Multiplexer 4051

5. Kabel jumper

6. Software Arduino

\subsubsection{Pengujian Sensor LDR (Light Dependent Resistor)}

\section{A. Tujuan Pengujian}

Tujuan dari pengujian sensor LDR bertujuan untuk mndapatkan nilai kelembaban itensitas cahaya(LUX). Nilai analog dari sensor akan diubah menjadi parameter itensitas cahaya dalam bentuk satuan persen(lux) sesuai dengan kebutuhan

\section{B. Peralatan Pengujian}

Peralatan yang dibutuhkan untuk pengujian sensor LDR adalah :

1. Mikrokontroler Node MCU

2. Sensor LDR dan rangkaianya

3. Kabel data usb

4. IC Multiplexer 4051

5. Kabel jumper

6. Software Arduino

\subsubsection{Pengujian Fuzzy Node MCU}

\section{A. Tujuan Pengujian}

Tujuan dari pengujian fuzzy Node MCU bertujuan untuk menerapkan metode fuzzy dalam pengambilan keputusan yang nanti akan dijadikan output alat ini sesuai dengan data dari input sensor.

\section{B. Peralatan Pengujian}

Peralatan yang dibutuhkan untuk pengujian fuzzy Node MCU adalah:

1. Mikrokontroler Node MCU

2. Kabel data usb

3. Software arduino

4. Sensor DHT 11 sebagai input

5. Relay $5 \mathrm{~V}$

6. Irigasi air sebagai output

\subsubsection{Pengujian Komunikasi dari Node MCU ke Server} $W e b$

\section{A. Tujuan Pengujian}

Tujuan dari pengujian komunikasi dari Node MCU ke server web bertujuan untuk mengirim parameter input ke web server yang nantinya akan dikirim ke telepon seluler pintar android lewat web server ini.

\section{B. Peralatan Pengujian}

Peralatan yang dibutuhkan untuk pengujian fuzzy Node MCU adalah:

1. Mikrokontroler Node MCU

2. Kabel data usb

3. Software arduino

4. Sensor DHT 11, soil moisture, dan LDR sebagai input

5. Akun server web ubidots.com yang sudah tersetting dengan 1 device 4 variabel seperti pad.

6. Koneksi WIFI atau telepon seluler yang ada teathringnya

\subsubsection{Pengujian Program Android}

\section{A. Tujuan Pengujian}

Tujuan dari pengujian program android bertujuan untuk aplikasi monitoring keadaan tanaman dengan memonitor suhu, kelembaban, dan cahaya berbasis IoT dengan aplikasi smartphone sehingga dapat diakses selama ada koneksi internet.

\section{B. Peralatan Pengujian}

Peralatan yang dibutuhkan untuk pengujian program android adalah:

1. Akun web server ubidots.com

2. Telepon seluler pintar

3. Koneksi internet

4. Software android studio

\subsubsection{Pengujian Alat Penyiraman}

\section{A. Tujuan Pengujian}

Tujuan dari pengujian fuzzy Node MCU bertujuan untuk menerapkan metode fuzzy dalam pengambilan keputusan yang nanti akan dijadikan output alat ini sesuai dengan data dari input sensor. 


\section{B. Peralatan Pengujian}

Peralatan yang dibutuhkan untuk pengujian program android adalah:

1. Mikrokontroler Node MCU

2. Kabel data usb

3. Software arduino

4. Sensor DHT 11, soil moisture, LDR sebagai input

5. Telepon seluler pintar

6. Koneksi internet

7. Software android studio

\section{HASIL DAN PEMBAHASAN}

\subsection{Hasil Pengujian Rangkaian Keseluruhan}

Dari hasil pengujian alat penyiraman dapat ditunjukkan dengan tabel 1. data dari tabel tersebut diambil acak dari percobaan dikarenakan data sebenernya setiap satu menit, tapi disini diambil satu jam saja untuk data.

Tabel 1. Hasil Pengujian Alat Penyiraman

(Sumber : Penelitian)

\begin{tabular}{|c|c|c|c|c|c|c|}
\hline \multirow{2}{*}{$\begin{array}{l}\text { Hari } \\
1\end{array}$} & \multirow{2}{*}{$\begin{array}{l}\text { Jam } \\
\text { cahaya } \\
05.00\end{array}$} & \multirow{2}{*}{$\begin{array}{l}\text { Suhu } \\
\text { Ket } \\
280\end{array}$} & \multicolumn{2}{|c|}{ Kel. Udara } & \multirow{2}{*}{$\begin{array}{l}\text { Kel. } \\
0,05 \text { lux }\end{array}$} & \multirow[t]{2}{*}{ Tanah } \\
\hline & & & \multirow{2}{*}{$72 \%$} & \multirow{2}{*}{$72 \%$} & & \\
\hline & \multicolumn{4}{|c|}{ Menyiram 13,6s } & & \\
\hline & 06.00 & 280 & $77 \%$ & $73 \%$ & 0,391 lux & \\
\hline & \multicolumn{6}{|c|}{ Tidak menyiram } \\
\hline & 07.00 & 280 & $80 \%$ & $75 \%$ & 1,46 lux & \\
\hline & \multicolumn{6}{|c|}{ Tidak menyiram } \\
\hline & 08.00 & 290 & $80 \%$ & $73 \%$ & $1,501 u x$ & \\
\hline & \multicolumn{6}{|c|}{ Tidak menyiram } \\
\hline & 09.00 & 290 & $75 \%$ & $74 \%$ & 4,36lux & \\
\hline & \multicolumn{6}{|c|}{ Tidak menyiram } \\
\hline & 10.00 & 290 & $78 \%$ & $76 \%$ & $3,76 \operatorname{lux}$ & \\
\hline & \multicolumn{6}{|c|}{ Tidak menyiram } \\
\hline & 11.00 & 300 & $73 \%$ & $77 \%$ & $3,501 u x$ & \\
\hline & \multicolumn{6}{|c|}{ Menyiram 14,6s } \\
\hline & 12.00 & 320 & $74 \%$ & $77 \%$ & 2,98lux & \\
\hline & \multicolumn{6}{|c|}{ Meyiram 14,6s } \\
\hline & 13.00 & 310 & $74 \%$ & $78 \%$ & 2,91lux & \\
\hline & \multicolumn{6}{|c|}{ Menyiram 14,6s } \\
\hline & 14.00 & 300 & $73 \%$ & $78 \%$ & 2,20lux & \\
\hline & \multicolumn{6}{|c|}{ Menyiram 14,6s } \\
\hline & 15.00 & 300 & $73 \%$ & $82 \%$ & 2,02lux & \\
\hline & \multicolumn{6}{|c|}{ Menyiram 14,6s } \\
\hline & & 300 & $74 \%$ & $82 \%$ & 2,18 & \\
\hline & \multicolumn{6}{|c|}{ Menyiram 14,7 } \\
\hline & & 300 & $73 \%$ & $82 \%$ & 2,02lux & \\
\hline & \multicolumn{6}{|c|}{ Menyiram 14,6\% } \\
\hline \multirow[t]{5}{*}{2} & 05.00 & 280 & $72 \%$ & $71 \%$ & $0,05 \operatorname{lux}$ & \\
\hline & \multicolumn{6}{|c|}{ Menyiram 13,6s } \\
\hline & 06.00 & 280 & $76 \%$ & $73 \%$ & 0,39lux & \\
\hline & \multicolumn{6}{|c|}{ Tidak menyiram } \\
\hline & 07.00 & 280 & $80 \%$ & $76 \%$ & $1,46 \operatorname{lux}$ & \\
\hline
\end{tabular}

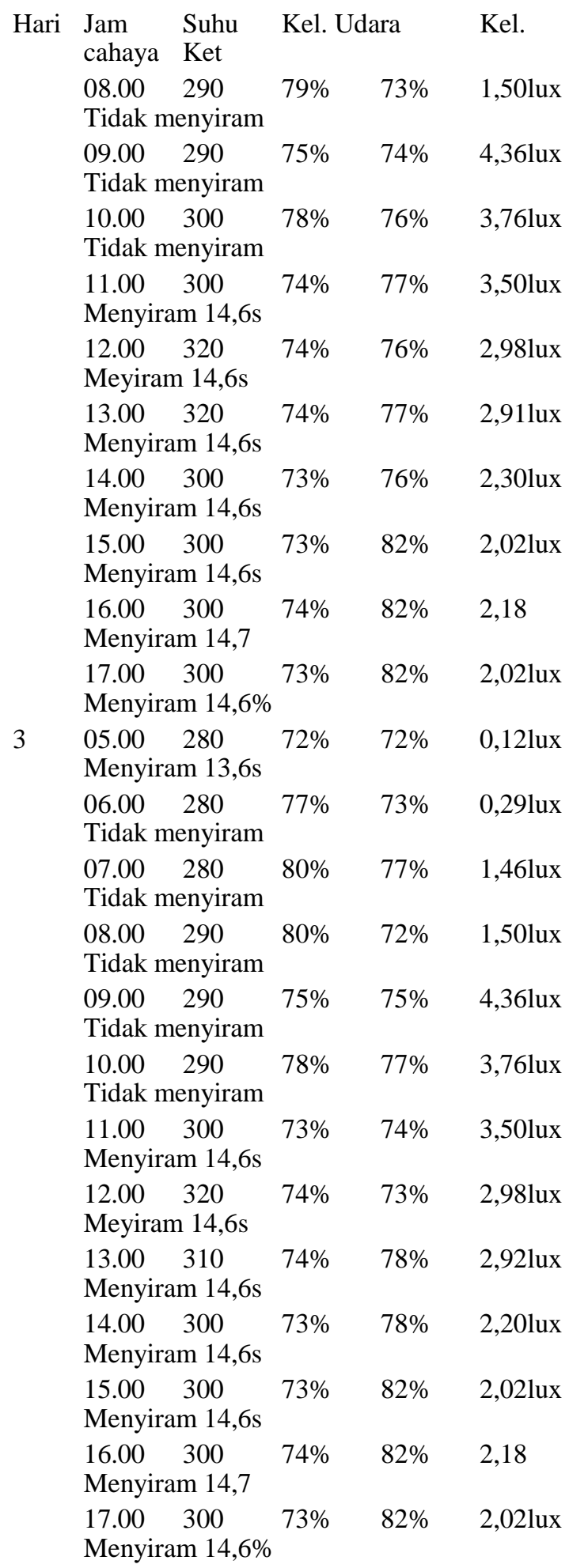

Dari data pada tabel 1 alat penyiraman ini dapat menyiram berkali-kali dikarenakan suhu dan kelembaban di daerah madura sangatlah jauh dari kriteria jamur. Untuk mendapatkan setpoint yang diinginkan itupun susah. Apalagi alat penyiraman ini ditempatkan di area perumahan yang mempunyai suhu panas. Sehingga alat ini akan menyiram terus sesuai dengan logika fuzzy yang sudah diatur. Berikut adalah grafik suhu dari hari pertama seperti yang ditunjukkan pada gambar 4 . 


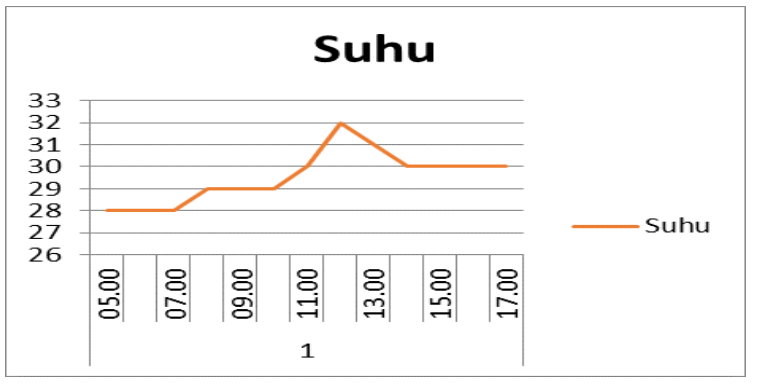

Gambar 4. Suhu dari waktu ke waktu.

(Sumber : Penelitian)

Dari gambar 4 diketahui pada siang hari suhu meningkat drastis dan pada waktu itu alat penyiraman selalu bekerja sampai mendapatkan nilai atau suhu yang diinginkan.

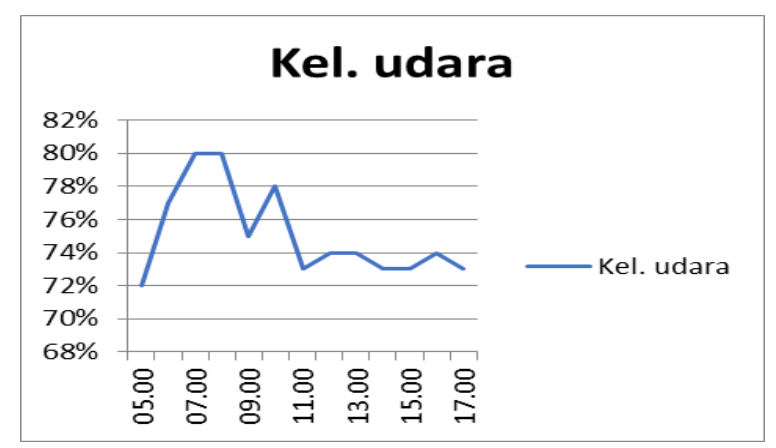

Gambar 5. Kelembaban udara dari waktu ke waktu. (Sumber : Penelitian)

Pada gambar 5 jelas terlihat pada waktu siang kelembaban udara mulai menurun, dan alatpun bekerja sesuai dengan logika fuzzy yang telah diset. Karena kelembaban udara berbanding terbalik dengan suhu. Jika kelembaban meningkat maka suhu relatif rendah begitu pula sebaliknya.

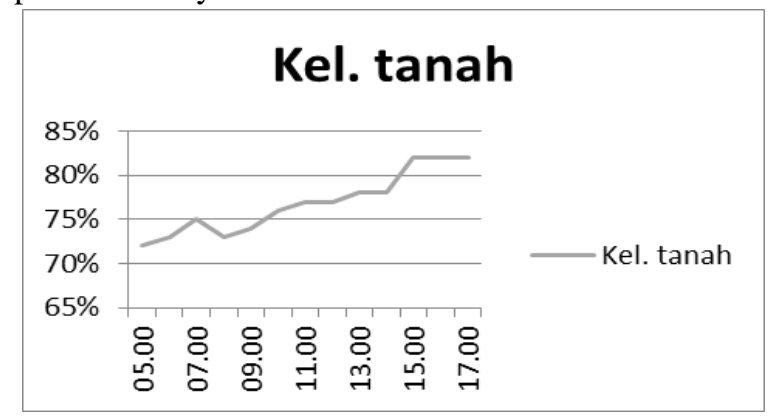

Gambar 6 Kelembaban tanah dari waktu ke waktu (Sumber : Penelitian)

Kelembaban tanah atau kelembaban baglog yang ditunjukkan gambar 6 dari waktu ke waktu semakin

meningkat dikarenakan alat penyiraman yang aktif bekerja sehingga baglog basah dan otomatis kelembaban baglog akan semakin meningkat.

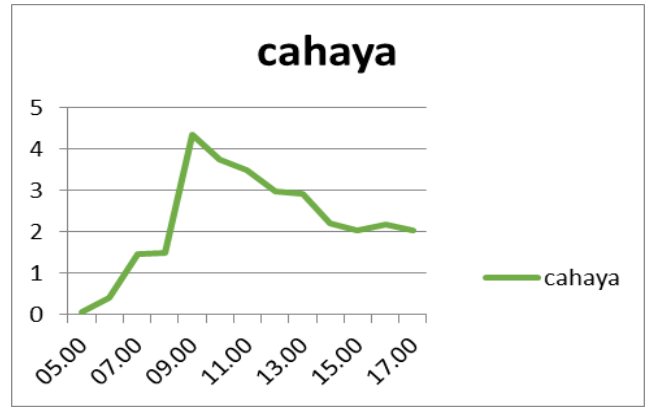

Gambar 7. itensitas cahaya dari waktu ke waktu.

(Sumber : Penelitian)

Dari gambar 7 jelas terlihat pada saat pagi itensitas cahaya kurang, dan puncak,,nya pada saat mulai waktu siang hari nilai itensitas cahaya akan selalu meningkat dan pada sore hari akan menurun intensitas cahayanya.

\section{KESIMPULAN}

Pengujian alat berhasil sesuai dengan metode yang diinginkanm, masing-masing sensor dapat bekerja dan mengendalikan aktuator atau outputnya masing. Alat juga dapat berkomunikasi dengan ponsel pintar dan prosentase keberhasilan alat sampai menumbuhkan jamur pada penelitian pertama adalah $100 \%$. Sistem komunikasi berjalan dengan baik, dengan bantuan web server dan koneksi internet maka alat dapat mengirim parameter ke server web yang selanjutnya dari ponsel pintar andorid akan mengambil data dari web server tersebut. Data dapat diakses dimana saja asalkan ada koneksi internet.

\section{REFERENSI}

[1] Pahruzi Muhammad, Abidin Zainal, Fridon M.A. "Rancang Bangun Alat Penyiraman Otomatis Menggunakan Sensor SHT75 Berbasis Mikrokontroler ATMEGA8535". Jurnal Ilmiah Mahasiswa, Volume 4, Nomer 1, Oktober 2015, Halaman 88-92.

[2] Yusuf Muhammad, Isnawaty, Ramadhan Rahmat. "Implementasi Robot Line Follower Penyiram Tanaman Otomatis Menggunakan Metode Proportional - Integral - Derivative Controller (PID)". SemanTIK, Volume 2, Nomer 1, Januari-Juni 2016, PP. 111-124.

[3] Nugrahaning Happy Widhi, Winarno Heru. "Sistem Penyiraman Tanaman Anggrek Menggunakan Sensor Kelembaban dengan Program Borland Delphi 7 Berbasis Modul Arduino Uno R3". Gema Teknologi, Volume 18, Nomer 1, Periode April 2014 Oktober 2014.

[4] Guptha Abhishek, Kumawat Shailesh, Garg Subham. "Automatic Plant Watering System". Imperial Journal of Interdisciplinary Research, Volume 2, Issue 4, 2016.

[5] Rahmawati, Diana (2014) Perancangan Sistem Kendali Cerdasa Rumah Kaca Hemat Energi Berbasis SMS (Short Message Service) Gateway, Prosiding Seminar Nasional Pendidikan dan Sains, UIN Semarang 2014

[6] Rahmawati, Diana (2015) Perancangan Kebun Mini Hemat Air dengan Sistem Mikroirigasi Fuzzy Otomatis menggunakan Arduino Laporan Penelitian Mandiri Universitas Trunojoyo Madura, LPPM UTM

[7] Rahmawati, Diana (2015) Desain Sistem Mikroirigasi Percik Otomatis berbasis Logika Fuzzy, Prosiding Seminar Nasional SNTT 2015, Politeknik Negeri Malang

[8] Rahmawati, Diana (2015) Design and Simulation of Mini Garden Fuzzy Microirrigation System, Proceeding of The International Conference on Vocational Education and Electrical Engineering (ICVEE)2015,UNESASurabaya. 